\title{
Time Management Techniques Required By Business Leaders in Enugu Metropolis
}

\author{
${ }^{1}$ Okoye H. I. \& ${ }^{2}$ Obi C. A. \\ ${ }^{I}$ Postgraduate Research Scholar, Department of Vocational Teacher Education, University of Nigeria, Nsukka \\ ${ }^{2}$ Professor of Business Education, Department of Vocational Teacher Education, University of Nigeria, Nsukka
}

\begin{abstract}
Time has become one of the most insufficient but very important resources in organizations. Applying workable time management techniques would therefore lead to improvement in productive capacity and better competitive edge in this post-industrial age. It would also bring about increased profit and provide a climate of reduced stress and job satisfaction among business leaders and their subordinates. This study determined the time management techniques required by business leaders in Enugu Metropolis. Survey research design was used. Four research questions and four hypotheses guided the study. The population comprised 150 business leaders randomly sampled from 25 organizations. Questionnaire validated by five experts was used for primary data collection. Reliability was established using Chronbach Alpha which result yielded a high reliability index of 0.88. Mean and standard deviation were used to analyze and answer the research questions, while t-test was used to test null hypotheses at .05 level of significance. Data analysis was done using Statistical Package for Social Sciences (SPSS) Version 17. The research found that four operationalized clusters of time management techniques were, for the most part, required by business leaders, thereby confirming the position of previous researchers on the issue. Based on the findings, it was recommended, among others, that business organizations should provide training opportunities for their staff to acquire the time management techniques identified by this research; develop internal manuals and procedures to guide their employees on best time management practices; and discourage physical and electronic-based activities that contribute nothing to productivity.
\end{abstract}

Key words: African time, business leaders, higher productivity, organizations, techniques, time, time management.

\section{Introduction}

In the pre-industrial age, the concept of time and time management depended on agricultural tempos, tides, weather, and seasons. According to Covey, Merrill \& Merrill (1994), supported by Nayab (2011), daylight hours determined work hours, inclement weather determined holidays, and productivity depended on the vicissitudes of the growing season. The sun and the moon actually determined time keeping. However, the industrial revolution ended the dependence on the weather as the invention of electricity and deployment of artificial lighting rendered the concept of daylight hours insufficient.

Time has now become a major subject of discussion and debate amongst scholars, philosophers and scientists. A generic definition of time which can address all dimensions and fields of study is still an unsolved puzzle for the greatest scholars till date and the scholarly community acknowledges this confusion (Muhammad, Nadeem, Hameed, Mobeen and Rahim, 2010). Nevertheless, Merriam-Webster (2013) gave a modern definition of time as a period during which an action, process or condition occurs - the period being measurable in units such as centuries, decades, years, months, weeks, days, hours, minutes and seconds.

As the pace of life increases, the perception of time changes. According to Taylor (2013), a decade seems to pass in a few years. In the present era, therefore, time is seen as the most insufficient of all available resources both in private and corporate organizations (Chukwmaeze, 2000; Busari, 2012). Tracy (2004) also stated that the single biggest shortage among employed people today is time. People suffer time poverty. They may have the money they need, but they do not have the time to enjoy it. As a result, free time is becoming more important than higher pay. Today, organizations will pay more for employees or services that save them time. This means that, although time management had its start over a hundred years ago, the need for it is greater today than ever. It should be treated as a precious resource which must be well managed along with other resources to achieve the goals of an organization. In the words of Williams (2002), there should be a structure to organize behaviours and events to take place with some degree of order. Time management as defined by Busari (2012) is the act or process of planning and exercising conscious control over the amount of time spent on specific activities, especially to increase effectiveness, efficiency or productivity. Technique is the systematic procedure, formulae or routine by which a task is accomplished (Business-Dictionary, 2013). Time management techniques (TMT) are therefore the systematic procedures, models or formulae applied to manage time. 
Time management techniques identified by different authors were, based on the key elements common in all, operationalized by the researchers under four clusters of planning, organizing, prioritizing and saving techniques. While planning techniques refer to the procedure applied to develop goals and schedules ahead of time, organizing has to do with systematic and orderly arrangement of the activities and materials needed to accomplish the predetermined goals (Management-Study-Guide, 2012). On the other hand, prioritizing techniques are the process of determining what tasks are more important with a view to allocating prime time to them. Saving techniques are strategies for avoiding "time wasters" that contribute nothing to productivity (Tracy, 2004).

Also, from the related literature reviewed, a number of models and methods of time management that support the techniques were also identified. For instance, SMART model for time planning emphasizes goal setting that is Specific, Measurable, Relevant and Time-bound; Locke's SPACE method of organizing which stands for Sort, Purge, Assign, Containerize and Equalize (Mindtools, 2013); the time quadrant model which prioritizes by categorizing activities as "urgent", "not urgent", "important", and "not important" (Covey, 1997); the $\mathrm{ABC}$ method which groups "A" tasks as urgent and important; "B" tasks as important but not urgent; and "C" tasks as neither important nor urgent (Lakein, 1973). There is also the Pareto 80/20 Rule formulated by Italian economist, Vilfredo Pareto, which stipulates that $80 \%$ of productivity is achieved by $20 \%$ of effective time use (Diane, 2012); and the POSEC method which stands for Prioritizing by Organizing, Streamlining, Economizing and Contributing (Process-Policy, 2013).

Many factors contribute to people's inability to apply the required time management techniques in corporate and personal lives. One of them is lack of training. Ekundayo, Konwea and Yusuf (2010) pointed out that time management like any other skill or technique can be learned. Also, modern technologies, as important as they are, have been implicated for employees' inability to maximize time use. Internet and email in particular have had a major impact on the way people work, but they have not all the time been for the good (BookBoon, 2010). In particular, Nigeria and other African societies are known to have peculiar and fundamental problem of a culture of "African time" which has persisted till this present period of knowledge economy and global workplace. African time is described as the tendency to maintain a relaxed, indifferent attitude towards time - a belief that no event will start at the absolute time scheduled (Harshman, 2011). According to Oke (2005), the general laxity of Africans about time pervades their collective attitude to work. They simply lack time discipline. This manifests in their politics and economy, as well as in other aspects of national life in almost all the countries on the continent.

The consequences of either not being time conscious or the inability to apply effective time management techniques in corporate and personal lives were identified. They include continuous lack of time to carry out essential duties; increased misunderstanding and confusion; lack of direction, purpose and commitment; frequent stampede or panic measures to beat deadlines; and lack of co-ordination and conflict in schedules. Hall and Hursch (1982) had also earlier observed that, generally in organizations where time management techniques are not applied, effectiveness are less, projects are not completed on time, human resources are wasted, and people are therefore, perhaps, not as happy as possible. Specifically speaking, staff are late to meetings and unprepared, appointments are overlooked, car repairs are not completed on time, work style is hectic and disorganized. There could also be many unfortunate consequences on a personal level. For instance, interpersonal relations deteriorate, professional competence is called into question, career and personal goals are unfulfilled, and individuals experience a hurried and harried work life. A study by National Association of Professional Organizers (2013) found that $80 \%$ of organizations' medical expenditures are stress related. Stress-related illness costs America $\$ 300$ billion a year in medical expenses and productivity. Office workers waste an average of $40 \%$ of their workday, not because they are not smart, but because they were never taught time management techniques to cope with increasing workloads. Nine million hours each day are wasted looking for lost and misplaced articles, $40 \%$ adults say if they had more time, they would spend it with family while business leaders waste 7.8 hours each week in meetings. Naturally, these would lead to decline in productivity and revenue for the organizations. The situation could be worse in Enugu, Nigeria, where employees have the additional burden of proclivity to "African time" which further complicates the problem of time management.

Conversely, business leaders who apply time management techniques would find that they are more productive, feel less stressed, are more available, relate more positively to others and feel better about themselves. This position was supported by Dodd and Sundheim (2005) and Chapman and Rupured (2012). Who are the business leaders? There are four levels of management functions in organizations: strategic, tactical, operational and clerical (Agomuo, 2005). Business leaders are found at the first three levels. Policy makers or business owners belong to the first level. Managers belong to the second while supervisors belong to the third. Those in the clerical grade usually need monitoring and supervision to carry out their own duties. They are the direct workers - intermediate or junior workers/artisans. By implication, managers and supervisors are business leaders found at the tactical and operational levels. How can we then clearly distinguish between the 
responsibilities of a manager and those of a supervisor? Lehman (2007) explained that a manager is responsible for people and resources while a supervisor is responsible for people and their daily actions. In other words, managers are responsible for the product (what) while supervisors are responsible for the process (how). What both groups, nevertheless, share in common are the responsibilities of planning, organizing and prioritizing production of goods and services as well as that of monitoring the performance of their subordinates. They need to apply time management techniques to achieve their targets and meet the set objectives of their organizations. To be great managers or supervisors, one should be a great leader since many of the world's most well known companies have serious smart people at the helm (Southwell, 2013). Different sizes of organizations exist even though different countries define sizes of businesses based on the role the organizations play in the economy (Salami, 2003). However, factors that generally define size include number of full time employees, capital, and level of turnover (Obi, 2011). Managers and supervisors work in SMEs that employ above 50 full time staff. This research investigated the time management techniques of managers and supervisors as business leaders in such organizations in Enugu metropolis.

\section{Statement of the Problem}

The business world has gone global, virtual and highly competitive. No organization can afford to lose a customer on account of delay in supply of product or service. Also, factors such as widespread corporate restructuring due to accelerated technological changes, information overload and outsourcing options have all combined to put seemingly unmanageable pressure on business leaders. On the personal level, it has led to family-work conflict and work-personal life conflict. Stress-related illnesses have also increased leading to absenteeism of workers and higher medical bills. In spite of new technologies, extended working hours with 24/7 connectivity, productivity in organizations would naturally be negatively affected by poor time management. Low productivity in organizations means low revenue and could ultimately lead to staff layoff with its attendant social and economic consequences. Time needed to accomplish multi-tasking organizational objectives has, therefore, become a very critical resource that must be efficiently managed along with other resources. Time as a natural phenomenon is highly limited and irretrievable once wasted. Again, Nigeria and other African societies have the additional problem of a culture of "African time" which manifests itself in laxity and lack of time discipline. Conversely, it has been proven that being time conscious and applying correct time management techniques would provide the panacea for meeting deadlines, expanding productive capacity of organizations, increasing revenue and expanding employment and other economic opportunities for nations. Related literature reviewed reported the need for more researches on time management and how it affects productivity in organizations. Most of the previous works, however, tended to focus mainly on specific issues such as procrastination, organizational culture, leadership style, family-work conflict, use of temporal structures, perceived control of time, Internet/email use, time pressure; and time use efficiency. None has attempted a holistic approach. The problem of this research is therefore to determine a comprehensive time management techniques required by business leaders in Enugu Metropolis, Nigeria, and by extension, any other leaders in this present era of intense global competition and fast-paced economic, social, and political lives.

\section{Objectives of the Study}

The major objective of the study was to find out the time management techniques required by business leaders in Enugu metropolis. Specifically the study sought to determine:

1) time planning techniques required by business leaders.

2) time organizing techniques required by business leaders.

3) time prioritizing techniques required by business leaders.

4) time saving techniques required by business leaders.

\section{Research Questions}

1) What are the time-planning techniques required by business leaders?

2) What are the time-organizing techniques required by business leaders?

3) What are the time-prioritizing techniques required by business leaders?

4) What are the time-saving techniques required by business leaders?

\section{Null Hypotheses}

$\mathrm{Ho}_{1}$ There is no significant difference in the mean ratings of managers and supervisors on time planning techniques required by business leaders.

$\mathrm{Ho}_{2}$ There is no significant difference in the mean ratings of managers and supervisors on time organizing techniques required by business leaders.

$\mathrm{Ho}_{3}$ There is no significant difference in the mean ratings of managers and supervisors on time prioritizing techniques required by business leaders. 
$\mathrm{Ho}_{4}$ There is no significant difference in the mean ratings of managers and supervisors on time saving techniques required by business leaders.

\section{Methodology}

Survey research design was used for the study which purpose was to obtain data by use of questionnaire based on rating scale. The study was carried out in Enugu metropolis. Enugu, at present, is made up of three Local Government Councils and has three fully developed industrial layouts accessible by bus, car, train and airplane (Okogbue, 2005). It has fast growing economy with many small and medium-sized enterprises (SMEs), but also a trajectory of firms that are collapsing and throwing people out of jobs. These informed the choice of the metropolis as the area of study. Twenty-five organizations were selected on the basis of their number of employees ( 50 full time staff and above). The population was 150 (50 managers and 100 supervisors, i.e. 2 managers and 4 supervisors per firm) randomly sampled from the main branches of the organizations. Four research questions and four hypotheses guided the study. A structured questionnaire of 60 items, developed from the literature reviewed and grouped into four clusters, was used for primary data collection. The instrument carried a 5-point scale of: Very Much Required (5), Required (4), Required on the Average (3), Somewhat Required (2), and Not Required (1). The instrument was validated by five experts - one management consultant, two business leaders and two lecturers from the Department of Vocational Teacher Education, University of Nigeria, Nsukka. The comments and suggestions of validates were used to modify and perfect the final instrument. Chronbach Alpha was used to establish the internal consistency and the result was 0.88 reliability index. Out of the 150 questionnaire administered, $140(93.3 \%)$ were retrieved and found to be duly completed. Mean and standard deviation were used to analyze and answer the research questions while independent samples t-test was used to test the null hypotheses. Data analysis was done with Statistical Package for Social Sciences (SPPSS) Version 17. The criterion for accepting the rating as required was the weighted (average) mean of 3.00 (i.e. $5+4+3+2+1=15 / 5=3.00$ ). Any mean rating of 3.00 and above was accepted as "Required" while any score below was regarded as "Not Required". For the hypotheses, if the p-value in each case was greater than .05 level of significance ( $p>.05)$ at 138 degree of freedom, it was upheld; otherwise it was rejected.

\section{Results}

The results are presented in line with the research questions and hypotheses that guided the study.

Table 1: Mean, standard deviation and independent samples t-test analysis of the respondents' ratings of time planning techniques required by business leaders $\mathrm{N}=140$ (44 Managers, 96 Supervisors); $\mathrm{df}=138$

\begin{tabular}{|c|c|c|c|c|c|c|c|c|c|}
\hline \multirow[t]{2}{*}{ Item } & \multirow[t]{2}{*}{ Technique Required } & \multicolumn{2}{|c|}{ Managers } & \multicolumn{2}{|c|}{ Supervisors } & \multirow[t]{2}{*}{ Rmks } & \multirow[t]{2}{*}{$\mathbf{t}$} & \multirow[t]{2}{*}{$\mathbf{p}$} & \multirow[t]{2}{*}{ Rmks } \\
\hline & & $\mathrm{X}_{1}$ & $\mathrm{SD}_{1}$ & $\mathrm{X}_{2}$ & $\mathrm{SD}_{2}$ & & & & \\
\hline 1 & Using the first $15-30$ minutes to plan each day & 4.16 & .834 & 4.35 & .767 & $\mathrm{R}$ & -1.359 & .176 & NS \\
\hline 2 & Planning each week and month ahead of time & 4.32 & .471 & 4.32 & .589 & $\mathrm{R}$ & -.047 & .963 & NS \\
\hline 3 & $\begin{array}{l}\text { Setting goals and allocating time for long-term } \\
\text { objectives/projects }\end{array}$ & 4.11 & .784 & 4.15 & .754 & $\mathrm{R}$ & -.232 & .817 & NS \\
\hline 4 & Preparing for meetings/conferences ahead of time & 3.98 & .590 & 3.93 & .669 & $\mathrm{R}$ & .427 & .670 & NS \\
\hline 5 & Crafting to-do-list, task plan or K.I.Vs & 3.55 & .730 & 3.64 & .848 & $\mathrm{R}$ & -.608 & .544 & NS \\
\hline 6 & $\begin{array}{l}\text { Reviewing schedules from time to time to } \\
\text { accommodate contingencies and to re-plan where } \\
\text { and when necessary }\end{array}$ & 3.77 & .677 & 3.83 & .721 & $\mathrm{R}$ & -.471 & 639 & NS \\
\hline 7 & $\begin{array}{l}\text { Blocking out part of the daily or weekly time for } \\
\text { major projects. }\end{array}$ & 3.98 & .664 & 3.98 & .632 & $\mathrm{R}$ & -.016 & .987 & NS \\
\hline 8 & $\begin{array}{l}\text { Breaking tasks into manageable bits for } \\
\text { subordinates and team members }\end{array}$ & 3.95 & .371 & 4.03 & .396 & $\mathrm{R}$ & -1.085 & .280 & NS \\
\hline 9 & $\begin{array}{l}\text { Using time log, wall planner, diary, calendar and } \\
\text { relevant electronic tools such as MS Outlook }\end{array}$ & 4.11 & .443 & 4.10 & .552 & $\mathrm{R}$ & .100 & .921 & NS \\
\hline 10 & Setting up template for weekly or monthly reports & 3.84 & .526 & 3.88 & 637 & $\mathrm{R}$ & -.310 & .757 & NS \\
\hline 11 & $\begin{array}{l}\text { Mutually developing measurable goals with } \\
\text { subordinates/team members }\end{array}$ & 4.20 & .408 & 4.25 & .503 & $\mathrm{R}$ & -.525 & .600 & NS \\
\hline 12 & $\begin{array}{l}\text { Providing for alternatives and use of flexitime } \\
\text { while planning activities to accommodate mobile } \\
\text { workers and those working in distant virtual } \\
\text { environments. }\end{array}$ & 4.14 & .462 & 4.06 & .723 & $\mathrm{R}$ & .622 & .535 & NS \\
\hline 13 & $\begin{array}{l}\text { Working out training programmes for } \\
\text { subordinates to implement long-term (strategic) } \\
\text { plans/projects }\end{array}$ & 1.45 & .589 & 1.46 & .695 & NR & -.031 & .975 & NS \\
\hline 14 & $\begin{array}{l}\text { Developing work simplification techniques and } \\
\text { setting standards based on these. }\end{array}$ & 1.39 & .538 & 1.47 & .632 & NR & -.749 & .445 & NS \\
\hline 15 & $\begin{array}{l}\text { Analyzing and improving performance standards } \\
\text { of subordinates through programmed training on }\end{array}$ & 3.34 & .834 & 3.53 & .807 & $\mathrm{R}$ & -1.282 & .202 & NS \\
\hline
\end{tabular}




\begin{tabular}{|c|c|c|c|c|c|c|c|c|c|}
\hline 16 & $\begin{array}{l}\text { sound time management techniques } \\
\text { Generally being proactive instead of reactive, e.g. } \\
\text { planning contact or dinner or details of } \\
\text { presentation ahead of time. }\end{array}$ & 4.23 & .424 & 4.17 & .592 & $\mathrm{R}$ & 610 & .543 & NS \\
\hline
\end{tabular}

Key: $X_{1}=$ Mean 1; $S D_{1}=$ Standard Deviation 1; $X_{2}=$ Mean 2; $S D_{2}=$ Standard Deviation 2; NS = Not

Significant; $R=$ Required $; N R=$ Not Required; $d f=$ Degree of Freedom; $N=$ No. of Respondents; $t=t$-values; $p=$ probability values (sig. 2-tailed)

Table 1 shows that 14 items of time planning techniques were rated by both groups of respondents as required, since their means were above 3.00. Two items were, however, rated as not required with their means ranging from 1.39 to 1.47 . The table equally indicates that all the items had their p-values greater than .05 level of significance at 138 degree of freedom. This means that there were no statistically significant differences in the mean ratings of managers and supervisors on time planning techniques required by the business leaders.

Table 2: Mean, standard deviation and independent samples t-test analysis of the respondents' ratings of time organizing techniques required by business leaders

$\mathrm{N}=140$ (44 Managers, 96 Supervisors); $\mathrm{df}=138$

\begin{tabular}{|c|c|c|c|c|c|c|c|c|c|}
\hline \multirow[t]{2}{*}{ Item } & \multirow[t]{2}{*}{ Technique Required } & \multicolumn{2}{|c|}{ Managers } & \multicolumn{2}{|c|}{ Supervisors } & \multirow{2}{*}{$\underset{\mathrm{R}}{\mathrm{R}}$} & \multirow[t]{2}{*}{$\mathbf{t}$} & \multirow[t]{2}{*}{$\mathbf{p}$} & \multirow[t]{2}{*}{ Rmks } \\
\hline & & $\mathrm{X}_{1}$ & $\mathrm{SD}_{1}$ & $\mathrm{X}_{2}$ & $\mathrm{SD}_{2}$ & & & & \\
\hline 17 & $\begin{array}{l}\text { Using the last } 15-30 \text { minutes to de-clutter desk } \\
\text { or workstation ready for the next day's job }\end{array}$ & 4.09 & .520 & 4.16 & .530 & $\mathrm{R}$ & -.681 & $\begin{array}{c}.49 \\
7\end{array}$ & NS \\
\hline 18 & $\begin{array}{l}\text { Immediately discarding papers or other } \\
\text { materials no longer needed }\end{array}$ & 3.82 & .657 & 3.84 & .621 & $\mathrm{R}$ & -.222 & $\begin{array}{c}.82 \\
5\end{array}$ & NS \\
\hline 19 & $\begin{array}{l}\text { Using electronic organizer (e.g. PDA, briefcase) } \\
\text { to advantage }\end{array}$ & 4.23 & .476 & 4.14 & .609 & $\mathrm{R}$ & .884 & $\begin{array}{l}.37 \\
8\end{array}$ & NS \\
\hline 20 & Handling each document once & 1.48 & .549 & 1.50 & .632 & NR & -.205 & $\begin{array}{c}.83 \\
8\end{array}$ & NS \\
\hline 21 & $\begin{array}{l}\text { Using in-basket for sorting mail, magazines, } \\
\text { notes, receipts, etc. }\end{array}$ & 3.59 & .658 & 3.74 & .669 & $\mathrm{R}$ & $\overline{-} \cdot \overline{2}$ & $\begin{array}{l}.22 \\
2\end{array}$ & NS \\
\hline 22 & $\begin{array}{l}\text { Keeping personal belongings in regular places } \\
\text { both at home and in the office }\end{array}$ & 4.20 & .509 & 4.10 & .672 & $\mathrm{R}$ & .880 & $\begin{array}{c}.38 \\
0\end{array}$ & NS \\
\hline 23 & $\begin{array}{l}\text { Assembling all tools, files, notepaper, pens etc } \\
\text { ahead of the day's job or ahead of scheduled } \\
\text { meeting(s) }\end{array}$ & 4.25 & .488 & 4.14 & .535 & $\mathrm{R}$ & 1.208 & .22 & NS \\
\hline 24 & $\begin{array}{l}\text { Setting up reminders on mobile phone or } \\
\text { personal computer/laptop }\end{array}$ & 4.14 & .409 & 4.11 & .494 & $\mathrm{R}$ & .364 & $\begin{array}{c}.71 \\
7\end{array}$ & NS \\
\hline 25 & $\begin{array}{l}\text { Using offline and online electronic paper } \\
\text { tucking system with a strong search engine }\end{array}$ & 1.48 & .590 & 1.48 & .615 & NR & -.017 & $\begin{array}{c}.98 \\
6\end{array}$ & NS \\
\hline 26 & $\begin{array}{l}\text { Organizing tasks, assigning them, delegating } \\
\text { responsibilities and ensuring that they are not } \\
\text { reversed (getting the monkey back) }\end{array}$ & 4.18 & .540 & 4.12 & .682 & $\mathrm{R}$ & .565 & $\begin{array}{c}.57 \\
3\end{array}$ & NS \\
\hline 27 & $\begin{array}{l}\text { In the home front, getting ready for the next } \\
\text { day, e.g. by laying out clothes, packing the } \\
\text { bag(s) and checking out the weather report }\end{array}$ & 4.27 & .758 & 4.32 & .624 & $\mathrm{R}$ & -.412 & $\begin{array}{c}.68 \\
1\end{array}$ & NS \\
\hline
\end{tabular}

Key: $X_{1}=$ Mean 1; $S D_{1}=$ Standard Deviation 1; $X_{2}=$ Mean 2; $S D_{2}=$ Standard Deviation 2; $N S=$ Not

Significant; $R=$ Required $; R=$ Not Required; $d f=$ Degree of Freedom; $N=$ No. of Respondents; $t=t$-values; $p=$ probability values (sig. 2-tailed)

Table 2 indicates that both groups of respondents rated 9 items of time organizing techniques as required and 2 as not required. The 9 items had their mean values above 3.00 while the two not required had theirs between 1.48 and 1.50 - below the cut-off mark. However, the Table indicates that all items had their pvalues above .05 level of significance. This implies that there were no statistically significant differences in the mean ratings of the two groups of respondents on time organizing techniques required by business leaders. 
Table 3: Mean, standard deviation and independent samples t-test analysis of the respondents' ratings of time prioritizing techniques required by business leaders

$\mathrm{N}=140$ (44 Managers, 96 Supervisors); $\mathrm{df}=138$

\begin{tabular}{|c|c|c|c|c|c|c|c|c|c|}
\hline 28 & $\begin{array}{l}\text { Starting the day by identifying the "urgent" and } \\
\text { "important" tasks first }\end{array}$ & 4.14 & .734 & 4.18 & .615 & $\mathrm{R}$ & 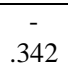 & .733 & NS \\
\hline 29 & $\begin{array}{l}\text { Tackling quadrant } 2 \text { activities first (i.e. the most } \\
\text { important and complex but productive) }\end{array}$ & 4.18 & .620 & 4.17 & .574 & $\mathrm{R}$ & .141 & .888 & NS \\
\hline 30 & $\begin{array}{l}\text { Applying the Pareto's } 80 / 20 \text { rule (i.e. being } \\
\text { conscious that } 80 \% \text { of productivity is made } \\
\text { possible by } 20 \% \text { of effective time use) }\end{array}$ & 3.68 & .883 & 3.80 & .626 & $\mathrm{R}$ &.- & .358 & NS \\
\hline 31 & $\begin{array}{l}\text { Labeling activities or "bullets" A,B,C according } \\
\text { to level of priority (i.e. using the ABC method) }\end{array}$ & 3.93 & .846 & 4.18 & .729 & $\mathrm{R}$ & $\begin{array}{c}- \\
1.76 \\
5\end{array}$ & .080 & NS \\
\hline 32 & $\begin{array}{l}\text { Assisting to prioritize and monitor subordinates' } \\
\text { own schedules }\end{array}$ & 1.43 & .545 & 1.47 & .632 & NR &. & .738 & NS \\
\hline 33 & $\begin{array}{l}\text { Re-setting priorities according to economic } \\
\text { conditions or work changes, e.g. re-organization } \\
\text { or new technology }\end{array}$ & 3.95 & .608 & 3.97 & .589 & $\mathrm{R}$ & - & .896 & NS \\
\hline 35 & $\begin{array}{l}\text { Ignoring less strategic schedules since no leader } \\
\text { can "do it all" in a day }\end{array}$ & 3.93 & .759 & 4.00 & .616 & $\mathrm{R}$ & $\begin{array}{c}- \\
.564\end{array}$ & .574 & NS \\
\hline 36 & $\begin{array}{l}\text { Concentrating on products or services that have } \\
\text { greatest potential for the organization }\end{array}$ & 4.23 & .605 & 4.23 & .571 & $\mathrm{R}$ & -018 & .986 & NS \\
\hline 37 & $\begin{array}{l}\text { Using project management software for large } \\
\text { projects }\end{array}$ & 4.25 & .576 & 4.17 & .556 & $\mathrm{R}$ & .815 & .417 & NS \\
\hline 38 & $\begin{array}{l}\text { Prioritizing based on how important Management } \\
\text { rates a project and the natural sequence of the } \\
\text { project }\end{array}$ & 3.95 & .914 & 4.06 & .737 & $\mathrm{R}$ & .745 & .458 & NS \\
\hline 39 & $\begin{array}{l}\text { Building effective bridges from goals to } \\
\text { accomplishments }\end{array}$ & 4.07 & .695 & 4.09 & .504 & $\mathrm{R}$ & - & .806 & NS \\
\hline
\end{tabular}

Key: $X_{1}=$ Mean 1; $S D_{1}=$ Standard Deviation 1; $X_{2}=$ Mean 2; $S D_{2}=$ Standard Deviation 2; NS = Not

Significant; $R=$ Required $; R=$ Not Required; $d f=$ Degree of Freedom; $N=$ No. of Respondents; $t=t$-values; $p=$ probability values (sig. 2-tailed)

The data in Table 3 shows that 13 items of time prioritizing techniques had their means rated above 3.00 by the two groups of respondents. This means that those techniques were required by the business leaders. On the other hand, two techniques (assisting to prioritize subordinates' schedules and scheduling top priority projects early in the week) were rated below acceptable mark, showing that they were not required. Nevertheless, all the items had their p-values greater than .05 level of significance. This supported the null hypothesis that there were no significant differences in the mean responses of managers and supervisors on the time prioritizing techniques required by business leaders.

Table 4: Mean, standard deviation and independent samples t-test analysis of the respondents' ratings of time saving techniques required by business leaders

$\mathrm{N}=140$ (44 Managers, 96 Supervisors); $\mathrm{df}=138$

\begin{tabular}{|c|c|c|c|c|c|c|c|c|c|}
\hline Item & Technique Required & \multicolumn{2}{|c|}{ Managers } & \multicolumn{2}{|c|}{ Supervisors } & Rmks & $\mathbf{t}$ & $\mathbf{p}$ & Rmks \\
\hline 43 & $\begin{array}{l}\text { Avoiding procrastination (e.g. by starting major } \\
\text { tasks first thing) }\end{array}$ & 4.16 & .776 & 4.24 & .557 & $\mathrm{R}$ & -.698 & .486 & NS \\
\hline 44 & $\begin{array}{l}\text { Eliminating "time wasters" (such as interruptions, } \\
\text { unplanned meetings, TV for leisure, Facebook, } \\
\text { online gaming) during office hours }\end{array}$ & 4.14 & .594 & 3.96 & .501 & $\mathrm{R}$ & 1.839 & .068 & NS \\
\hline 46 & $\begin{array}{l}\text { Avoiding self-inflicted burnout that may lead to } \\
\text { breakdown in health with the attendant time loss }\end{array}$ & 4.14 & .554 & 4.09 & .504 & $\mathrm{R}$ & .450 & .653 & NS \\
\hline 47 & $\begin{array}{l}\text { Saying "gentle" no to unplanned discussions or } \\
\text { questions from drop-in visitors }\end{array}$ & 4.05 & .714 & 3.97 & .570 & $\mathrm{R}$ & .681 & .497 & NS \\
\hline
\end{tabular}




\begin{tabular}{|c|c|c|c|c|c|c|c|c|c|}
\hline 48 & $\begin{array}{l}\text { Using secretary or PA to screen and control } \\
\text { potential distracters }\end{array}$ & 1.45 & .548 & 1.48 & .632 & NR & -.223 & .824 & NS \\
\hline 49 & $\begin{array}{l}\text { Being in control without allowing conferences } \\
\text { and meetings to wander }\end{array}$ & 4.07 & .587 & 3.91 & .563 & $\mathrm{R}$ & 1.558 & .121 & NS \\
\hline 50 & $\begin{array}{l}\text { Using voice mail while setting up time to return } \\
\text { calls only once or twice a day }\end{array}$ & 3.86 & .795 & 3.93 & .623 & $\mathrm{R}$ & $\begin{array}{c}- \\
.5044\end{array}$ & .615 & NS \\
\hline 51 & Ensuring that delegated tasks have end dates & 3.86 & .905 & 4.03 & .656 & $\mathrm{R}$ & 1.240 & .217 & NS \\
\hline 52 & $\begin{array}{l}\text { Putting "Do Not Disturb" sign when handling } \\
\text { complex or important jobs }\end{array}$ & 3.95 & .645 & 4.06 & .612 & $\mathrm{R}$ & -.952 & .343 & NS \\
\hline 53 & Scheduling set times for checking emails & 3.89 & .754 & 3.86 & 609 & $\mathrm{R}$ & .182 & .856 & NS \\
\hline 54 & $\begin{array}{l}\text { Setting up email client that helps filter and file } \\
\text { email messages }\end{array}$ & 4.05 & 680 & 4.20 & .515 & $\mathrm{R}$ & 1.464 & .145 & NS \\
\hline 55 & $\begin{array}{l}\text { Turning off instant messaging features or deleting } \\
\text { junk and spam mails immediately they pop up }\end{array}$ & 4.20 & .734 & 4.02 & .754 & $\mathrm{R}$ & 1.350 & .179 & NS \\
\hline 56 & $\begin{array}{l}\text { Avoiding situations that lead to repeats, e.g. } \\
\text { sending email to wrong addresses }\end{array}$ & 3.50 & .976 & 3.74 & .954 & $\mathrm{R}$ & $1 . \overline{369}$ & .173 & NS \\
\hline 57 & $\begin{array}{l}\text { Simplifying work methods and systems to } \\
\text { prevent regular questions from subordinates }\end{array}$ & 4.09 & .676 & 4.21 & .560 & $\mathrm{R}$ & 1.077 & .283 & NS \\
\hline 58 & Using mechanized and automated processes & 3.91 & 640 & 3.89 & .679 & $\mathrm{R}$ & .195 & .846 & NS \\
\hline 59 & $\begin{array}{l}\text { Occasionally standing up while talking just to } \\
\text { keep the conversation brief }\end{array}$ & 4.00 & .571 & 3.98 & .562 & $\mathrm{R}$ & .203 & .840 & NS \\
\hline 60 & $\begin{array}{l}\text { Avoiding multi-tasking, e.g. gathering papers for } \\
\text { meeting, working on the computer and attending } \\
\text { to a guest - all at the same time }\end{array}$ & 3.91 & .563 & 3.95 & .587 & $\mathrm{R}$ & -.368 & .714 & NS \\
\hline
\end{tabular}

Key: $X_{1}=$ Mean 1; $S D_{1}=$ Standard Deviation 1; $X_{2}=$ Mean 2; $S D_{2}=$ Standard Deviation 2; NS = Not

Significant $R=$ Required $; R=$ Not Required; $d f=$ Degree of Freedom; $N=$ No. of Respondents; $t=t$-values; $p=$ probability values $($ sig. 2 -tailed)

The data in Table 4 reveals that 16 out of the 17 items of time saving techniques were rated as required by both groups of respondents, since their means were all above 3.00. Only one item (use of secretary or PA to screen visitors) scored 1.45 and 1.48 in Mean 1 and Mean 2 respectively. This means it was rated not required. All the items, however, had their respective p-values greater than .05 level of significance. The null hypothesis of no significant differences was therefore upheld for all the items of time saving techniques.

\section{Discussion of the Findings}

The findings of the study (Table 1) showed that 14 out of 16 time planning techniques were required by business leaders in Enugu Metropolis. These include: the use of the first 15 - 30 minutes to plan each day; planning each week and month ahead of time; crafting to-do-list; using time log, wall planner and electronic tools; setting up template for weekly or monthly reports; providing for alternatives and use of flexi-time, among others. This agrees with the views of Tracy (2004) and Philip-King (2013) that creation of a work plan ensures that all essential areas are covered and investment in time planning pays a 1,000 percent on time and energy spent doing so. The respondents might have considered the two techniques they rated not required as having been covered by others rated as required.

The result of Table 2 also revealed that 9 organizing techniques were required. These were, among others, the use of the last 15 - 30 minutes to de-clutter desk or workstation; use of electronic organizer; keeping personal belongings in regular places; setting up reminders on computers; and getting ready for next day's job before retiring to bed at home. The respondents' support for organizing techniques is in line with the views of Busari (2002) and Taylor (2012) that working in organized environment increases efficiency and that many brilliant successful business leaders are highly organized people. However, the respondents rated two items (handling papers once and use of electronic tucking system) as not required. It is suggestive that they were "guilty" of paper shuffling and were not yet using the state-of-the-art technology of electronic paper tucking system as an organizing tool.

Research question 3 (Table 3) revealed that 13 prioritizing techniques were considered by the respondents as required with their means ranging from 3.68 to 4.25 . The techniques included: identifying urgent and important tasks first; tackling the most productive jobs first; use of Pareto's 80/20 rule; use of ABC method; use of project management software; use of POSEC method; creating balance between work and recreation centers, among others. Their position is supported by Bregman (2013) who averred that prioritizing allows one to focus on the most productive tasks and that it is inevitable since a person can work 24/7 and still not meet up. Two techniques rated as not required were on prioritizing for subordinates and scheduling project early in the week. The respondents might have felt that subordinates should be able to prioritize on their own, given proper training; and that scheduling projects early in the week might not be necessary if tasks were to be prioritized on daily basis.

The result from Table 4 indicated 17 time-saving techniques required as against only one technique rated as not required. Their mean scores were well above 3.00. The techniques required included but were not 
limited to: avoiding procrastination; eliminating time stealers (e.g. TV, Facebook, drop-in visitors); saying gentle "no" to unplanned discussions/meetings; occasional use of "Do Not Disturb" sign; scheduling time for emails; and avoiding repeats. The overwhelming rating in favour of time saving techniques agreed with the positions of Wetmore (2005) and Blair (2013) who emphasized that time management itself means time saving - anytime one is not saving time, the person is wasting it - and the most important activities are those which will save ones time at work and at home. The only technique rated as not required was the use of personal assistant (PA) or secretary to screen potential distracters. The respondents might have considered it obsolete in this new era when office technology tends to reduce need for secretaries at those levels. Secretaries or PAs work with the chief executives (only at the strategic level) where some organizations cannot entirely dispense with their services, no matter the level of technology available.

The findings from Tables $1-4$ also revealed relatively close range in standard deviations in all cases for both groups of respondents. This means there was no much dispersion in their opinions. Again, the p-values for all the 60 items were greater than .05 level of significance at 138 degree of freedom, thereby supporting all four hypotheses that there were no statistically significant differences in the mean ratings of managers and supervisors on time management techniques required by business leaders.

\section{Conclusion and Recommendations}

Managers and supervisors in modern organizations are business leaders who have common responsibilities of achieving targets in product or service delivery. They require time management techniques to meet up. It is therefore not surprising that the two groups of respondents overwhelmingly rated almost all the time management techniques identified by this research as required, and showed no statistically significant differences in their mean ratings of all the techniques. Their position is in line with that of Tracy (2004) supported by Alesandra (2013) that business leaders who apply proper time management techniques would achieve higher productivity and impressive return on investment as well as live a more fulfilling life in and out of office. Those who lack time discipline would naturally respond slowly to needs or orders, their organizations would be seen to be poorly run, and they would hardly meet up with the demands of their offices in this era of highly competitive global business climate. Based on the findings of the research, therefore, the following recommendations were made:

1. Business leaders, particularly those in Nigeria and other African countries where people have proclivity to "African time", should be re-oriented to practice the time management techniques identified by this research in order to continually improve their individual and group performance indicators.

2. Organizations should consider training their staff at all levels on the time management techniques. This is because the managers and supervisors believe that even their subordinates should prioritize their own tasks by themselves.

3. They should integrate time management into their strategic human resource practice and process reengineering. This they will achieve by developing manuals and procedures to guide their staff to ensure that the application of best time management practices becomes part of their organizational culture.

4. Organizations should also guard against time wasting activities that contribute nothing to productivity. In particular, they should monitor their staff on technological obsession or misuse, e.g. unregulated and excessive use of Internet, intranet, email and social networks.

5. As part of wellness programme, organizations should equally encourage their staff to practice time management techniques that include leisure, even if such appears "unproductive". This will reduce stressrelated illnesses and save them money and time spent in hospitals and medical bills.

\section{References}

[1]. Covery, S.R., Merrill, R. \& Merrill, R.R. (1994). First Things First: to Live, to Love, to Learn, to Leave a Legacy. USA: Simon \& Schuster Publishing.

[2]. Nayab, N. (2011). Exploring the history of time management. Bright Hub Inc. Available @ http://www.brighthub.com

[3]. Mohammad, U.S., Nadeem, E.F., Hameed, F., Mobeen, A.K., \& Rahim, J. (2010). High level principles of time management in Islam. Singapore: International Conference on Social and Economic Development, IPED (10). IACSIT Press.

[4]. Merriam-Webster Online Dictionary (2013). Definition of time management. Merriam-Webster Incorporated. Available @ http://www.merriam-webster.com/dictionary/workplace.

[5]. Taylor, H. (2013). The changing face of time management. Taylor Time Consulting. Available @ http://www.taylorintime.com/index.php?option...id.

[6]. Chukwumaeze, O.O. (2000). Time management. A paper delivered at Management Workshop for Secretaries and PAs. Aba: Centre for Management Development, 15 - 19 May.

[7]. Busari, O. (2012). Time Management. A paper delivered at the Advanced Strategic Public Relations Protocol \& Travel Management Course. Dubai: Foreign Corporate Training Ltd (FCTL), 23 - 27 July.

[8]. Tracy, B. (2004). Time Power. New York: American Management Association.

[9]. Williams, E.K. (2002). Harnessing the river of time: a theoretical framework of time use efficiency. Journal of Employment Counseling, 39 (1). Available @ http://www.questia.com/library/191-83983444/.

[10]. Business-Dictinary (2013). Supervisor - definition and meaning. Web-Finance Inc. Retrieved from http://www.businessdictionary.com on 17/01/2013. 
[11]. Management-Study-Guide (2012). Time management - meaning and its importance. Available @ http://www.managementstudyguide.com.

[12]. Mindtoos (2013). Time management: beat work overload, be more effective and achieve more. Mindtools-Corporate. Available @ http://mindtools.com.

[13]. Covey, S.R. (1997). The Seven Habits of Highly Effective People. Retrieved from http://www.businessinsider.com/stepehencoveys-7-habits-of-highly... on 12/01/2013.

[14]. Lakein, A. (1973). How to Get Control of your Time and Life. New York: Nal Penguin Inc.

[15]. Diane, C. (2012). Theories on workload and time management. Houston Chronicle. USA: Hearst Communications Inc.

[16]. Process-Policy (2013). Parkinson's Law in time management. Available @ http://processpolicy.com/parkinsons-law.htm.

[17]. Ekundayo, H.T., Konwea, P.E. \& Yusuf, M.A. (2010). Towards effective time management among lecturers in Nigerian universities. Journal of Emerging Trends in Educational Research and Policy Studies (JETERAPS), 1(1). Schorlinks Research Institute.

[18]. BookBoon (2010). Successful time management. MTD Training \& Ventus Publishing.

[19]. Harshman, C.T. (2011). What time is it? Who cares? It is African time. North of Lagos: Retrieved from www.northoflagos.com on $16 / 03 / 2013$

[20]. Oke, M. (2005). From an African ontology to an African epistemology: a critique of J.S. Mbiti on the time conception of Africans. QUEST - An African Journal of Philosophy/Revue Africaine de Philosophie, XVIII, 25-36.

[21]. Hall, B.L. \& Hursch, S. (1982). An evaluation of the effects of a time management training programme on work efficiency. Journal of Organizational Behaviour Management, 3(4). West Virginia University: The Harworth Press Inc.

[22]. NAPO (2013). Organizing and time management statistics. National Association of Professional Organizers. Available @ www.simplyproductive.com/category/-business-organizing. Retrieved on 14/04/2013.

[23]. Dodd, P. \& Sondheim, D. (2005). The Best 25 Time Management Tools and Techniques: How to Get More Done Without Driving Yourself Crazy. Capstone Publishing Ltd.

[24]. Chapman, L. \& Rupured, C. (2012). Strategies for better time management. University of Georgia: Learning for Life Cooperative Extension. Retrieved from www.fcs.uga.edu/ext/pubs/time-management.pdf on 20/02/2013.

[25]. Agomuo, E.E. (2005). Modern Office Technology - Issues, Procedures and Practice. Nsukka: University of Nigeria Press.

[26]. Lehman, L.B. (2007). Supervisor or manager: what is in a name? Rising Sun Consultants Ltd.

[27]. Southwell, A. (2013). Thirty most innovative business leaders of 2013. WordPress Inc. Available @ www.businessmanagement.net.

[28]. Salami, A.T. (2003). Guideline and stakeholders responsibilities in small and medium industries equity investment scheme (SMIEIS). Central Bank of Nigeria (CBN) Seminar. Lagos: CBN Training Centre.

[29]. Obi, C.A. (2011). Elements of Business. $3^{\text {rd }}$ ed. Owerri: De-Verge Agencies Ltd.

[30]. Okogbue, J.O. (2005). Enugu: origin and development. Owerri: The Image, 1(1).

[31]. Bregman, P. (2013). A personal approach to organizational time management. Organization Practice, January edition. Mckinsey \& Company. Retrieved from http://www.mcknsey.com on 20/02/2013.

[32]. Wetmore, N. (2013). Time savers - five time saving techniques. Retrieved from http://www.balancetime.com on 20/02/2013.

[33]. Blair, G.M. (n.d.). Personal time management for busy managers. United Kingdom: University of Edinburgh, ChartwellBratt. Available@ http://www.gerard@ee.ed.ac.uk.\&www.work911.com/.../ on 20/02/2013.

[34]. Alessandra, T. (2013). Time management. Retrieved from www.alessandra.com.../timemanagement_articles.asp. on 16/06/2013. 